\title{
Investigation on the Construction of Cooperative Education Mode for Applied Talents in the Tourism Management
}

\author{
Yonghong Bao*, Jingying Wang
}

Inner Mongolia Normal University, Hohhot 010022, Inner Mongolia, China. E-mail: baoyonghong_ly@163.com

Project: This thesis is the final result of the scientific research project of colleges and universities in Inner Mongolia Autonomous Region, "Research on the Cultivation mode of tourism talents from the perspective of national culture" (No. NJSY16035).

Abstract: With the reform and development of higher education in our country, the mode of "integration of production and education, cooperative education" has become an effective way to train application-oriented talents in colleges. It is significant for tourism management, as the major of more practicality and application, to carry out cooperative education actively in order to train the practical talents in travel industry. The cooperative education as the guiding ideology of teaching runs throughout the curriculum system, teaching material construction, practical teaching link, teaching method, teaching evaluation and so on of tourism management specialty, in order to realize the overall cooperative education mode, train the large number of applied talents of tourism industry, and promote the sustainable and healthy development of travel industry in the future.

Keywords: Tourism Management; Applied Talents; Collaborative Education Model

In terms of the development trend of tourism industry at home and abroad, the demand for applied talents of tourism specialty is increasingly fierce in recent years. Nowadays, the mode of training talents in tourism management cannot be in accordance with the actual demand, causing the imbalance of talents supply in tourism industry. It is not high for the employment rate of the tourism management graduates who can choose jobs relevant to their majors, and the corporations related tourism has become talents lacunae. According to this, taking the integration of industry and education and the mode of cooperative education in tourist market will ensure to support the colleges and universities the development and innovation of tourism management specialty to provide talent support for promoting the progress of tourism industry in China.

\section{To build a professional teaching system and a common goal of talent training by college-enterprise cooperation}

The construction of teaching system is the foundation to realize the training goal of tourism management professionals. The traditional teaching mode cannot make the teaching essence of tourism management match the needs of industry development in the past. The single pattern of teaching limits the development of students' professional practice ability and innovation ability, and concentrates on the cultivation of students' professional knowledge, which causes the lack of combining theory with practice so it is no longer sufficient for the actual demand of tourism industry. Therefore, the construction of tourism management curriculum system should be led by the universities and assisted by enterprises. At the same time, both universities and enterprises should jointly formulate the educational goals for collaborative education, and tourism enterprises should effectively feedback the training standards of tourism management professionals to the universities in terms of their own development demands. Thereby, it can draw up a perfect target of training professional applied talents.

Copyright(C) 2020 Yonghong Bao et al.

doi: 10.18686/ahe.v4i10.2876

This is an open-access article distributed under the terms of the Creative Commons Attribution Non-Commercial License (http://creativecommons. org/licenses/by-nc/4.0/), which permits unrestricted non-commercial use, distribution, and reproduction in any medium, provided the original work is properly cited. 


\section{To strengthen the construction of teaching materials and teaching resources for professional courses}

The teaching material of professional courses the basic condition to guarantee the quality of teaching. It is the main basis for teachers to carry out teaching. Choosing the suitable and superior teaching materials for tourism management will be beneficial to teachers' "teaching" and students' "learning", and help students to grasp the professional theoretical knowledge comprehensively. With the development of society and the rapid progress of tourism industry, colleges and universities must advocate the principle of forefront renewal in the selection of teaching materials, actively adopt professional curriculum teaching materials which have strong authority and high applicability, and focus on the main teaching materials which are promoted by the Ministry of Education at the national or local level. Universities should encourage and support corporations' authoritative talents and professional teachers to investigate the compilation of teaching materials, and promote tourism management courses to meet the practical needs.

\section{To build a collaborative education platform for college-enterprise cooperation}

To promote and actively seek the applied talents training mode of cooperation between college and enterprise, colleges and universities should be throughout the process of teaching. Colleges and universities could acquaint the market needs of the tourism industry before teaching adequately, actively build a platform for cooperative education and communication between universities and enterprises, and establish a practice base of professional curriculum for talent training and enterprise technology research, which can achieve mutual win-win cooperation between colleges and enterprises that take advantages of both sides, make up for deficiencies, and achieve the goal of jointly cultivating applied talents. It is practically significant for colleges, enterprises and society. The sharing of enterprises and educational resources is beneficial to promote the teaching development of tourism management and improving the counterpart employment rate and enterprises' employment levels.

\section{To set up a science practice teaching}

\subsection{Pay attention to the training of practical ability}

Due to the high demand for students' practical ability in tourism management, it is important to focus on the cultivation of students' practical ability. In this view, colleges and universities should optimize the construction of professional teaching hardware resources, and build practical training laboratories through cooperation between schools and enterprises, like hotel management training operation room, travel agency management training operation room and so on. At the same time, in the process of practical training, it is important to dare to innovate teaching, implement practical courses such as tourism catering management training, tourism etiquette service training, simulation tour guide training and so on by enterprise experts' help. In this way can students transform the theory knowledge of tourism management into practical skills and facilitate the effective integration of teaching theory and practice.

\subsection{Build a practical teaching system}

The training of undergraduate applied talents in colleges and universities is aimed at training top talents with strong practical application ability. The teaching of tourism management should combine classroom training, comprehensive training, enterprise probation, social practice and so on, which can promote teaching and social industry demand. Meanwhile, we must strengthen the construction of professional practice training base, the routine internship, internship organic combination. Making good use of summer holiday between the second and third grades of undergraduate, the students could be arranged to participate the practices which lets students take part in the practical work of tourism enterprises ahead of time. The teachers also could pass on the knowledge points in advance that is involved in the next stage to students in the period of summer practice, which can promote students to have a general perceptual understanding of new knowledge. In this way, can it strengthen students their practical ability and promote a deeper understanding of new knowledge next semester. This kind of teaching and practice interactive novitiate method effectively complements the traditional teaching mode and facilitates the rapid transformation of theoretical knowledge. On the other hand, students can find some difficult and key problems through this process, and then go back to the classroom to discuss and study that they can solve together, and further promote the improvement of teaching.

\section{To enrich the teaching methods}

In the new period of carrying out quality-oriented education in a comprehensive way, the undergraduate education in 
colleges and universities should fully comply with the change of educational concept, improve teaching methods and methods, and effectively ensure the quality of teaching. According to the teaching content, teachers should enrich teaching methods, innovate teaching means, carry out enlightening and discussion teaching, use advanced multimedia teaching technology, apply teaching methods flexibly, and diversify teaching models by the methods of situational simulation teaching, case teaching, project teaching, flipping classroom teaching. It is an effective to arouse students' subjective initiative in learning, stimulate students' enthusiasm and interest in learning, strengthen innovative thinking and consciousness, and improve the of independent problem analysis ability.

\section{To build the perfect teaching evaluation system \\ 6.1 Strengthen the supervision of professional teaching quality}

According to the training goal of tourism management, it is indispensable to formulate the corresponding teaching quality standards, the teaching inspection and supervision system and the teaching achievement evaluation system. It is also necessary to strengthen the quality supervision of each link of teaching and improve the teaching quality control system.

\subsection{Establish the evaluation system of teaching results jointly between colleges and enterprises}

It is important for both colleges and enterprises to formulate the evaluation mechanism of teaching results and actively implement. When tourism management students are comprehensively evaluated, the basis could be supported by professional skills enterprises talents' participation. Simultaneously, colleges and universities should set up enterprise satisfaction investigation mechanism, graduate tracking and visiting mechanism to know the on-the-job adaptation of students after graduation. Besides, tourism enterprises should build students' vocational ability feedback mechanism to objectively assess and evaluate on-the-job graduates, and feedback the evaluation results to the school.

\section{To strengthening the construction of teachers in universities}

These are one of the elements ensure the training goal of professional applied talents by strengthening the construction of teachers in tourism management and improving the strength of teachers. Thus, colleges and universities should expand the scale of teachers, establish a team of part-time teachers, and create a of composite teachers. First of all, the universities should actively introduce a group of excellent teachers with high academic qualifications, high professional titles and high teaching ability on the basis of the original teachers. It should also strengthen the internal teacher management training, constantly improve their professional skills and teaching ability, which can optimize and adjust the teacher structure. Secondly, in terms of the cooperation opportunities between schools and enterprises, professional teachers are regularly arranged in batches to participate in tourism enterprises to increase the practical experience and skills of professional teachers, to make them doublequalified teachers with both professional theory and practice, and to improve the ability of practical teaching solid foundation. Colleges and universities owing conditions and abilities should encourage and arrange outstanding young teachers to join in the further studies in well-known colleges and universities and even abroad. It is also important to participate in lectures, training and conferences on the construction of tourism specialties at the national, provincial and municipal levels. The universities should constantly innovate new trends of thought in teaching, and learn from and learn new teaching methods. Thirdly, colleges and universities should expand the development channels of the double-teacher team, and invite the industry elite and outstanding talents with strong professional skills and rich experience in the enterprise to conduct knowledge and skills lecture training on a regular basis, so that the classroom teaching and the industry can connect seamlessly. The last but not the least, colleges and universities should establish a perfect mechanism for selecting and hiring part-time teachers, select some industry senior people and senior managers as visiting expert teachers from enterprises, carry out regular teaching lectures, enrich students' knowledge and vision so that it can promote college professional teaching to meet the needs of society.

\section{References}

1. Zhao A. Construction and implementation of the model of integration of industry and education in tourism manage men_-The case of Liaodong University. Journal of Mudanjiang College of Education 2019; (4): 45-47.

2. Wang C, Fan J. Research on innovation of training mode of tourism management professionals based on "cooperative training”. Journal of Inner Mongolia University of Finance and Economics 2014; 12(6): 70-75. 